\title{
PAPILIO AJAX.
}

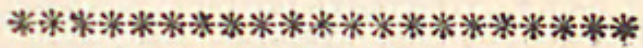

CHARACTER GENERICUS.

Antenna apicem versus crassiores, sæpius cla= vato-capitatæ.

Ala (sedentis) erectæ sursumque conniventes. (Volatu diurno.)

$$
\text { Lin. Syst. Nat. }
$$

CHARACTER SPECIFICUS, Eंc.

Papilio alis caudatis concoloribus flavescentibus, fasciis nigris geminatis; posticis subtus striga diffracta anguloque ani sanguineis.

Smith. Abbot Ins. Amer. t. 4. Papilio Ajax. P. alis obtuse caudatis concoloribus fuscis; fasciis flavescentibus, angulo ani fulvo.

$$
\text { Lin. Syst. Nat. p. } 750 .
$$

Georgiam et Virginiam incolit Papilio Ajax, cujus larva Annonæ palustris folia præcipue depascitur. 
4 ans:

$\sin$

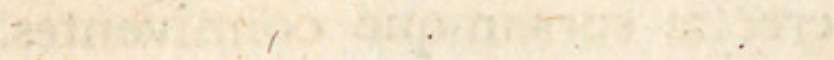

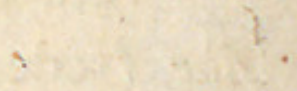

$\therefore \rightarrow \infty$

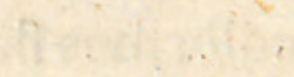

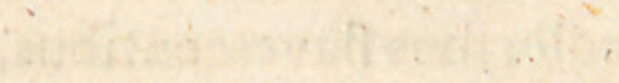

Chation

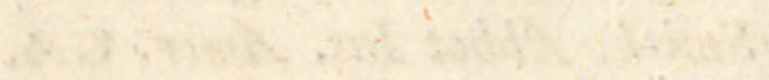

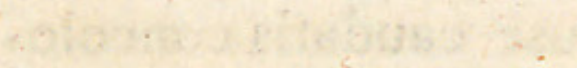

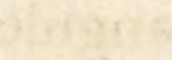

1 


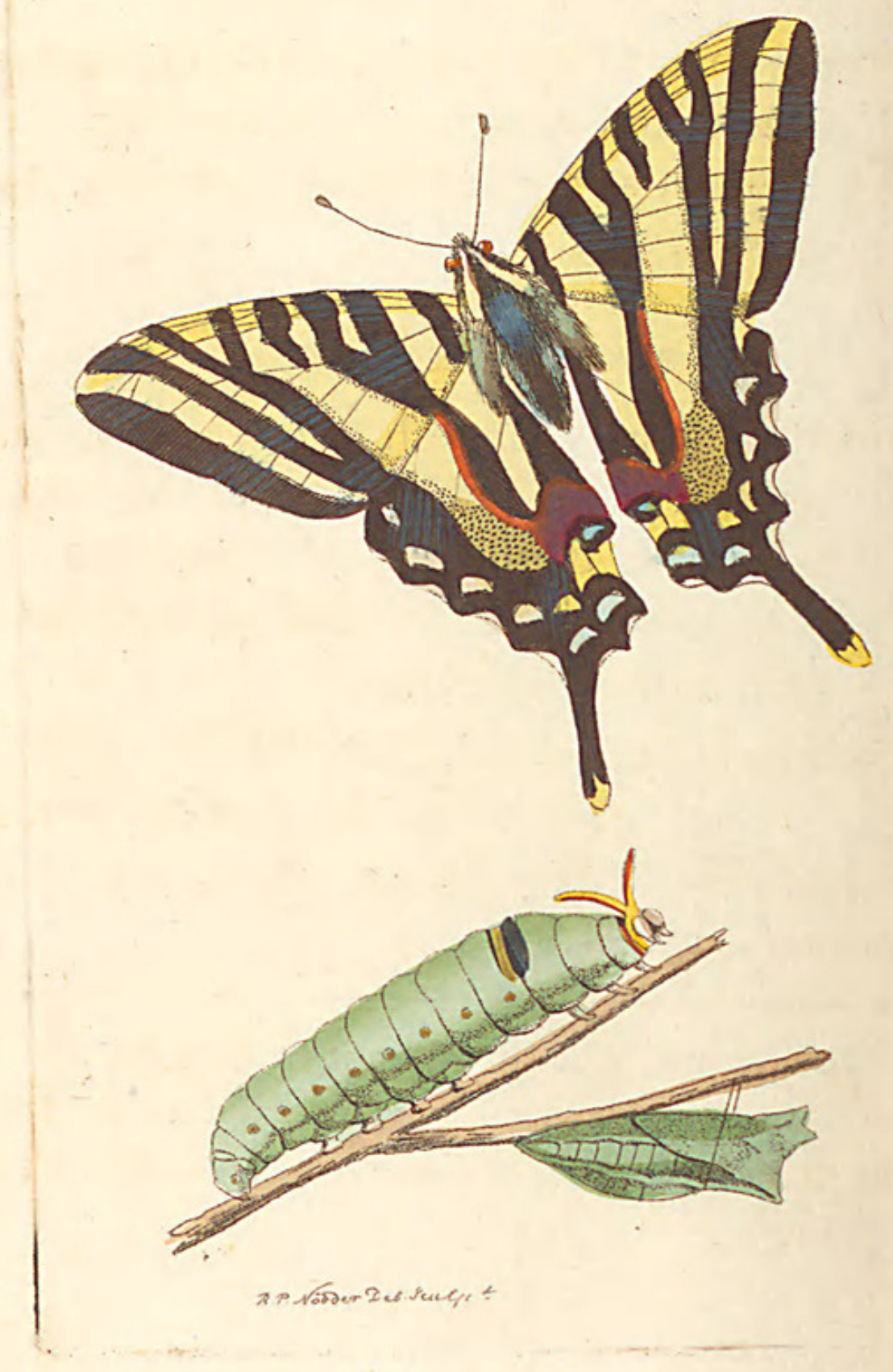


\section{AJAX.}

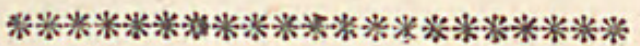

GENERIC CHARACTER.

Antenne thickening towards the end, and generally terminating in a clavated tip.

Wings (when at rest) meeting upwards. Flight diurnal.

SPECIFIC CHARACTER, Eंc.

Butterfly with yellowish-white tailed wings, marked in a similar manner on both surfaces with double black bands; the lower pair marked beneath and at the inner tips by a broken red stripe.

The Black-Barred Swallow-Tail Butterfly. Abbot's N. American Insects, pl. 4. P. Marcellus. Crämer Pap. pl. 89. f. G. н. Edwards, pl. 34 .

This insect is an inhabitant of Georgia and Virginia; the caterpillar feeding principally on the leaves of the Annona palustris of Linnæus, or Swamp Papaw. 


\section{$2 \mathrm{BHL}$ Biodiversity Heritage Library}

Shaw, George. 1812. "Papilio ajax, Ajax [PI. 1024]." The Naturalist's Miscellany 24(CCLXXVII), -. https://doi.org/10.5962/p.322304.

View This Item Online: https://www.biodiversitylibrary.org/item/296719

DOI: https://doi.org/10.5962/p.322304

Permalink: https://www.biodiversitylibrary.org/partpdf/322304

\section{Holding Institution}

Museums Victoria

\section{Sponsored by}

Atlas of Living Australia

\section{Copyright \& Reuse}

Copyright Status: Public domain. The BHL considers that this work is no longer under copyright protection.

This document was created from content at the Biodiversity Heritage Library, the world's largest open access digital library for biodiversity literature and archives. Visit BHL at https://www.biodiversitylibrary.org. 